\title{
Investigation of the Effect of Level of Family Needs Coverage that Nursing Care Given to Family with Disabled Children
}

\author{
Engelli Çocukların Ailesine Verilen Hemşirelik Bakımının Aile \\ Gereksinimini Karşılama Düzeyine Etkisinin İncelenmesi
}

\author{
Elif Bilsin ${ }^{1 *}$, Zümrüt Başbakkal ${ }^{1}$
}

ÖZET

\begin{abstract}
Amaç: Bu araştırma, engelli çocukların ailesine verilen hemşirelik bakımının aile gereksinimini karşılama düzeyine etkisini incelemek amacıyla yapılmıştır. Yöntem: Yarı deneysel olarak planlanmıştır. Araştırmanın evrenini Ocak-Nisan 2012 tarihleri arasında Gaziantep ilinde bulunan Sosyal Hizmet ve Rehabilitasyon Merkezinin evde bakım hizmetine kayıtlı 0-18 yaş arasındaki engelli çocuklar ve aileleri oluşturmuştur. Araştırmanın örneklemini ise basit rastgele örnekleme yöntemiyle seçilen 30 zihinsel/fiziksel/işitme/görme engelli çocuk ve aileleri oluşturmuştur. Çalışmada ailelerin gereksinimlerini belirlemek ve belirlenen gereksinimlere göre hemşirelik girişimleri planlamak, uygulamak ve değerlendirmek için her aileye ziyaretler arasında en az bir ay süre bırakılarak, en az üç kez ev ziyaretleri yapılmıştır. Araştırmada "Çocuk Tanıtım Formu", "Aile Tanıtım Formu", "Aile Gereksinimlerini Belirleme Aracı (AGBA)" ve "Hasta Çocuk Tanılama Formu" kullanılmıştır. Bulgular: Hemşirelik bakımı öncesi ailelerin AGBA toplam puan ortalaması $64.13 \pm 9.79$ iken hemşirelik bakımı sonrası $51.23 \pm 7.27$ olduğu saptanmıştır. Sonuç: Bu sonuçlar, engelli çocuklar ve ailelerine ev ziyaretleri ile verilen hemşirelik bakımının ailelerin gereksinimlerini azaltmada etkili olduğunu göstermektedir.
\end{abstract}

Anahtar kelimeler: Engelli çocuklar, hemşirelik bakımı, aile gereksinimi

\begin{abstract}
Objective: The purposes of this study are to evaluate disabled children and their parents in an integrated manner, to determine the needs and to examine the effect of nursing care services on meeting the family needs. Method: The study was planned as quasi-experimental. The target population of the study consisted of disabled children between 0 and 18 years of age and their parents who have been registered to the homecare service provided by the Child and Youth Center Directorate in Gaziantep during January to April 2012. The sample group of the study consists of 30 mentally/physically/hearing/visually disabled children who were selected by the simple random sampling method. At least three home visits were made to each family during the study in order to determine the needs of the family and to determine the nursing needs related with these needs, to plan the approaches, apply and evaluate them with at least one month between each visit. Child Description Form, Caregiver and Family Description Form, Family Needs Assessment Tool (FNAT) and Child Diagnosis Form were used during the study. Results: The FNAT total mean score of family was found to be $64.13 \pm 9.79$ before nursing care and $51.23 \pm 7.27$ after nursing care. Conclusion: These results demonstrate the effect of nursing care with home visit in reducing the needs of families with disabled children.
\end{abstract}

Keywords: Children with disability, nursing care, family needs

Received / Geliş tarihi: 24.02.2016, Accepted / Kabul tarihi: 2.11.2016

${ }^{1}$ Ege Üniversitesi Hemşirelik Fakültesi

*Address for Correspondence / Yazışma Adresi: Elif Bilsin, Ege Üniversitesi Hemşirelik Fakültesi, İzmir- Türkiye E-mail: elifbilsin$86 @$ hotmail.com

Bilsin E and Başbakkal Z. Investigation of the Effect of Level of Family Needs Coverage that Nursing Care Given to Family with Disabled Children, TJFMPC, 2017;11(1): 10-19. DOI: 10.21763/tjfmpc.295638 


\section{INTRODUCTION}

According to the World Health Survey and the Global Burden of Disease data; it is estimated that $15.6-19.4 \%$ of the world's population are disabled. Due to to these estimates, in 2010, given that the world's population is 6.9 billion, 5.04 billion of whom are over 15 years of age, number of disabled people over 15 years of age is changing between 785 to 975 million. 6.9 billion with 5.04 billion 15 years and over and 1.86 billion under 15 years with disability. ${ }^{1}$

Having a disabled child has significant effects on family life. Studies concluded that disability in a child has significant adverse effects on family life, including parents and siblings ${ }^{2}$ and causes various negative effects on the mental health of parents. ${ }^{3,4}$

In addition to the emotional problems the family must confront, families with disabled children have also various needs in other dimensions including economic, knowledge, care, medical, social life and homecare due to the intense parenting responsibilities. ${ }^{5-7}$

Published descriptive studies of parents of disabled children have generally focused on their sense of self, depression levels, styles of coping with stress, perceived social support levels and intra-familial harmony, family load, homecare need as well as the difficulties faced. ${ }^{2,4,12}$ However, nursing care is only mentioned in a few studies even though its important role in health care. Families of disabled children need support from outside the family as well as expert advice because of the needs of the disabled child such as care, treatment, education and acquisition of various social skills. The homecare service provided for disabled children can enable family members to spend more quality time with each other, thus decreasing or eliminating the physical, emotional and social problems that the children or parents might face. ${ }^{8}$ In this regard, nurses who work with disabled children and their families both at the hospitals and at social health centers have important roles regarding care given to both the family and the child. It is important to determine the family needs and to plan and execute the nursing services accordingly so that nursing services can be further developed in family-centered homecare services.

\section{Objective}

The objectives of this study are to evaluate disabled children and their parents in an integrated manner, to determine their needs and to examine the effect of nursing care services on meeting the family's need.
The study addressed the following research questions:

Research Question 1: Does nursing care given to families with disabled children reduce their family needs?

Research Question 2: Is there a difference between the mean scores of Family Needs Assessment Tool (FNAT) and its subscales before and after nursing care?

\section{Methods}

\section{Design}

The study was planned as quasi-experimental.

\section{Sample and Characteristics}

The target population of the study consisted of disabled children between 0 and 18 years of age, and their parents who have been registered to homecare service provided by the Child and Youth Center Directorate (CYCD) in Gaziantep during January to April 2012. The sample group of the study consists of 30 mentally / physically / hearing and/or visually disabled children who were selected by a simple random sampling method. According to power analysis, FNAT needs to have a sample size of $16(\alpha=0.05,1-\beta=0.80)$ in order to show 10 points difference between before and after measurements

\section{Inclusion Criteria}

- Physically, mentally, hearing and/or visually disabled children between 0 and 18 years of age,

- Families who agree to participate in the study,

- Families who have been registered with homecare service provided by CYCD in Gaziantep,

- Parents not having mental, hearing and/or visual disabilities,

The sociodemographic distribution of the families determined that the mean age of the mothers was $35.80 \pm 7.90$ years. Of mothers, $6.7 \%$ are secondary school graduates where as $53.3 \%$ of the fathers are primary school graduates. In all families, mother is primarly responsible from the care of the disabled child. Consequently, none of the mothers work outside the home in any of the cases studied where as $78.6 \%$ of the fathers are employed. Of families, $83.3 \%$ have social security; for $53.3 \%$ the income is equal to the expenses. Almost half $(43.3 \%)$ of the parents have 4 or more children.

Among disabled children, $30 \%$ are between the ages of 4 and 6 years; $30 \%$ are between the ages of 7 and 12 years; $53.3 \%$ are male; $80 \%$ are 
mentally unstable and also have a physical disability; $93.3 \%$ do not have a disabled sibling; and $80 \%$ have never attended school.

\section{Procedure}

Approvals were received from the Ethics Committee and Ministry of Family and Social Policies. The permission for using scale is obtained via e-mail form the author who carried out the validity and reliability study.

\section{Intervention}

A face to-face interview method was used by the researcher with the participant families after the required explanations about data acquisition forms used in the study. The health report of the child was used to obtain the necessary information included in the Child Description Form. Information for the Sick Child Diagnosis Form was obtained from the mother and via pediatric physical examination.

The researcher who made the home visits had a graduate bachelor's degree and was in the process of completing a Master's Degree in Child Health and Disease Nursing. In addition, the researcher had a four-month experience in child nursing and was a child health and disease research assistant for two years. The researcher attended lessons on a developmental approach to disabled children and their parents for a semester during the Master's education; she completed her apprenticeship at the Children's Hospital Neurology Clinic where families with disabled children are monitored. The care needs of disabled children and their families is presented in a lesson content.

The data acquisition tool for the children was completed in about five minutes, for the family in about five minutes and FNAT in about 15 minutes; the information listed in the data acquisition tool was acquired in about 30 minutes for children who were ill.

A meeting at CYCD was carried out during January 1-20, 2012 to present information about the study to the parents, to receive written and verbal consents and to enable them to meet with the researcher following the determination of the addresses of the disabled children registered in the home care service of CYCD. All home visits were made by a single researcher. Home addresses and phone numbers of families who agreed to participate in the study were recorded. The day of the home visit was determined via phone call before every home visit. At least three home visits were made for each family during the study to determine the needs of the family and to determine the nursing needs related to these needs, to plan and apply the approach, and to evaluate the family needs, with at least one month between each visit.

The Child Description, Family Description Form, FNAT and Child Diagnosis Form were filled during the first visit. Nursing diagnoses were made based on the acquired data, proper nursing interventions were planned and applied, and the family was trained. Nursing diagnoses made by NANDA according to the data acquired from the Sick Child Diagnosis Form and appropriate nursing interventions were planned and carried out during home visits. A nursing care plan was made for each family $(n=30)$ during the home visits.

During the second visit, an evaluation was carried out via a nursing procedure to determine whether the mother has been able to carry out the required care interventions in accordance with the training (oral care, body care, nutrition, medical care, rehabilitation, disabled rights, for instance). Nursing interventions were evaluated during the last visit, and the family was reassessed by using the FNAT.

Several families did not want to carry out some nursing interventions due to their resistance to change the situation of their children, assuming the child won't recover from disability or that the recommendations will increase the care burden of the mother. For these reasons, some nursing interventions have been evaluated as negative.

First home visits were made between January 23 and February 9, 2012, the second home visits were made between February 28 and March 9, 2012 and the third home visits were made between March 29 and April 15, 2012.

\section{Tools and Materials}

The Child Description Form, Caregiver and Family Description Form, FNAT and Child Diagnosis Form were used during the study.

\section{Child Description Form}

The Child Description Form was prepared by the investigators according to relevant literature. The description form consists of various questions including the age, gender, number of siblings, current health status of the child. There were also questions to determine whether or not the child is going to the rehabilitation center, and if so, then what is the frequency and duration of attendence per week. Their educational levels as well as the factors that caused their disability were also asked. 


\section{Caregiver and Family Description Form}

The Caregiver and Family Description Form was prepared by the investigators in line with literature. ${ }^{2,5-10}$ The description form consists of the socio-demographic data of the family as well as their coping status, health problems that are observed in the caregiver resulting from the child care burden, the most needed applications during care giving as well as what those applications are.

\section{Family Needs Assessment Tool-FNAT}

The FNAT was developed by Bailey and Simeonsson (1988); the validity and reliability works of the FNAT were carried out by Sucuoğlu (1995) and consists of two sections:

Section I: In this section, there are 35 items in six subgroups to enable parents to become aware of their needs. The first group includes seven items for the information needs of parents, the second group has eight items for support needs, the third group has five items under the heading of helping to explain the child's condition to others, the fourth group has five items on community services, the fifth group has six items related to financial needs of the family and the sixth group has four items for needs related to general family functioning. Each item included in this section is answered as 1 (definitely no), 2 (not sure) and 3 (definitely yes). The total scale score is obtained by summing the scores from each item. The total scale score has a minimum 35 and a maximum 105 points.

Section II: There is an open-ended question in this section expressed as "Please list the five most essential needs of your family". This question aims at identifying more specific needs of families that are not included in Section I.

The reliability of the data obtained through this tool was explored by Bailey and Simeonsson (1988) using the test-retest method, and the correlation of the scores obtained at the end of these two assessments was found to be $r=0.67$ for mothers and $r=0.81$ for fathers. Sucuoğlu (1995), at the end of his factor analysis study carried out with data obtained from 44 mothers and 45 fathers who had mentally retarded and autistic children, found that the Cronbach alpha internal consistency coefficient of the tool was 0.90. The adapted Turkish version of the FNAT has been used previously in Turkey with families of children with a hearing disability.

\section{Sick Child Description Form}

Various nursing case histories and family evaluation forms were examined to create a comprehensive database for the child and the family. The diagnosis form includes questions about introductory information, the birth story of the child, sickness status, dependency level for daily living activities, feeding, excretion, sleep, game-activity status, physical evaluation (height, weight, and other relevant information) as well as findings related to the life of the child and the family. In addition to this information, there are also questions that evaluate the physical examination data that covers all of the child's body structures, as well as questions for the evaluation of the psychomotor, psychosocial, cognitive and psychosexual development and communicative ability of the child. Nursing diagnoses were made by using International North American Nursing Diagnosis Association (NANDA) criteria and the data acquired from the Sick Child Diagnosis Form. After the diagnosis appropriate nursing interventions were planned and carried out.

\section{Statistical Analysis}

Sociodemographic characteristics of the family and children, disability-related characteristics of children, their care and nursing diagnosis were evaluated in percentages and frequencies. The Kruskall Wallis and the Mann Whitney U tests were used to determine the relationship between FNAT and FNAT subscale scores before and after nursing care, according to the sociodemographic characteristics of the family and child. Pearson correlation analysis was used to determine the relationship between FNAT and FNAT subscales scores before and after nursing care according to the mother's time spent in daily child care and the mean age of the mothers. One sample t-test used to evaluate mean scores of FNAT and FNAT subscales before and after nursing care. A paired sample $t$ test compare mean scores of FNAT and FNAT subscales before and after nursing care.

\section{RESULTS}

When the families asked whether or not they knew that their child will have a disability beforehand, 93.3\% stated that they have did not expect a disabled child. On the other hand, all participants expressed that they could cope with the disability. In $40 \%$ of the families, fathers also participated in disabled child's care in addition to mothers. More than one-third $(36.7 \%)$ of the mothers experience lumbago and lumbar hernia resulting from the difficulty of taking care of a disabled child. Almost all mothers $(96.7 \%)$ stated that they have anxiety about the future. Our results showed that mothers need help in many dimentions. Of mother in our study, $86.7 \%$ needed help for toilet care, $83.3 \%$ for cleaning and washing, $70 \%$ for treatment costs, $70 \%$ for social life and $66.7 \%$ for economic 


\begin{tabular}{|c|c|}
\hline Characteristics related to disability & n (\%) \\
\hline \multicolumn{2}{|l|}{ Health problems besides disability* } \\
\hline Salivation & $14(46.7)$ \\
\hline Constipation & $6(20.0)$ \\
\hline Tooth decay & $10(33.3)$ \\
\hline Epilepsy & $6(20.0)$ \\
\hline Bronchitis-asthma & $10(33.3)$ \\
\hline Scoliosis & $1(3.3)$ \\
\hline Myopia & $2(6.7)$ \\
\hline Incontinence & $2(6.7)$ \\
\hline Kidney disease & $1(3.3)$ \\
\hline Phenylketonuria & $1(3.3)$ \\
\hline \multicolumn{2}{|l|}{ The level of mental deficiency (n:25) } \\
\hline Mild & $5(20.0)$ \\
\hline Moderate & $3(12.0)$ \\
\hline Severe & $17(68.0)$ \\
\hline \multicolumn{2}{|l|}{$\begin{array}{l}\text { Enrollment rehabilitation center } \\
(\mathbf{n}: 30)\end{array}$} \\
\hline Yes & $21(70.0)$ \\
\hline No & $9(30.0)$ \\
\hline \multicolumn{2}{|l|}{$\begin{array}{l}\text { Frequency of child go to the } \\
\text { rehabilitation center }(\mathrm{n}: 21)\end{array}$} \\
\hline Once a week & $14(66.7)$ \\
\hline Twice a week & $7(33.3)$ \\
\hline \multicolumn{2}{|l|}{ The child's diagnosis* } \\
\hline Mental disability & $25(80.0)$ \\
\hline Physical disability & $25(80.0)$ \\
\hline Hearing disability & $3(10.0)$ \\
\hline Visual disability & $4(13.3)$ \\
\hline Chronic diseases (phenylketonuria) & $1(3.3)$ \\
\hline \multicolumn{2}{|l|}{ Reasons of children's disability } \\
\hline Genetic disorder & $12(40.0)$ \\
\hline Birth trauma & $7(23.3)$ \\
\hline Asphyxiation at birth & $2(6.7)$ \\
\hline Child's illness & $8(26.7)$ \\
\hline Other reasons & $1(3.3)$ \\
\hline \multicolumn{2}{|l|}{ Using medication (n:30) } \\
\hline Yes & $17(56.7)$ \\
\hline No & $13(43.3)$ \\
\hline
\end{tabular}

*More than one choice was marked.

concerns. When most frequently filled out applications by mothers were examined, it was observed that $93.3 \%$ were for cleaning-washing, $90 \%$ were for feeding, $86.7 \%$ were for care giving. It was determined that the mean number of hours that mothers spend for daily child care is $6.40 \pm$ 1.94 .

The disability status of the child as well as the distribution for disability in children according to their disability-related characteristics are shown in Table 1.
When the total and subscale scores of FNAT examined according to sociodemographic data, it was observed that the total mean score of FNAT in the families with children aged between 4 and 6 years $(70.88 \pm 9.0)$ was higher when compared with other age groups. It was determined that the "Financial Need" subscale score was higher for families with children between the ages of 0 and 3 years, the "Information Need" subscale score was higher for families with children between the ages of 4 and 6 years, and the "Support Need" and "Explanation to Others Need" subscale scores were higher in families with children between the ages of 7 and 12 years. A statistically significant difference was determined between the child age and the FNAT total score, "Information Need" and "Support Need" subscale score means $(\mathrm{p}<0.05)$. It was determined that the mean total FNAT scores and information need of the families with children aged between 4 and 6 years is greater, whereas the support need of the families with children aged between 7 and 12 years is greater.

The FNAT total scale score for families with girls is $66.50 \pm 9.58$, and for families with boys is $62.06 \pm 9.80$. In families with girls, FNAT total score, "Information Need", "Support Need", "Explanation to Others Need", "Financial Need" and "Family Functioning Need" scores are higher. On the other hand "Social Service Need" subscale score means are higher in families with boys. But only "Support Need" subscale score differed at a statistically significant level with respect to gender $(\mathrm{p}<0.05)$. It was determined that families with girls have a greater need for support.

The mean total FNAT score of families with low economic status $(67.80 \pm 5.05)$ were greater than the mean total score. There was a statistically significant difference between the total FNAT and "Financial Need" subscale scores regarding economic status of families $(p<0.05)$ indicating the need for financial support of families with inadequate economic status is higher.

There were no correlation between the number of hours that mothers spent for taking care of the child and the total FNAT scores and the FNAT subscale scores $(\mathrm{p}>0.05)$. A negative and statistically significant correlation was determined between the mean age of the mother and the "Information Need" subscale score $(p<0.05)$, whereas a highly significant and negative correlation was also determined with the "Support Need" subscale score $(\mathrm{p}<0.001)$. Information and support needs of young mothers are higher.

A statistically significant difference was determined between the FNAT total scores, "Information Need", "Support Need", "Explanation 


\begin{tabular}{|l|l|l|l|}
\hline \multicolumn{3}{|l|}{ Table 2. Families' mean scores of FNAT and FNAT subscales before and after nursing care } \\
\hline Scales & M \pm SD & T-test & P Value \\
\hline Total FNAT score & & & \\
\hline $\begin{array}{l}\text { Before nursing care } \\
\text { After nursing care }\end{array}$ & $64.13 \pm 9.79$ & 15.736 & $0.001^{*}$ \\
\hline Need for information & $51.23 \pm 7.27$ & & \\
\hline Before nursing care & & & \\
\hline After nursing care & $15.30 \pm 2.62$ & 18.073 & $0.001^{*}$ \\
\hline Need for support & $8.06 \pm 1.11$ & & \\
\hline Before nursing care & & & $0.001^{*}$ \\
\hline After nursing care & $18.20 \pm 2.67$ & 20.931 & \\
\hline Help explaining to others & $15.30 \pm 2.23$ & & \\
\hline Before nursing care & & & $0.001^{*}$ \\
\hline After nursing care & $6.46 \pm 2.06$ & 6.546 & \\
\hline Community services & $4.70 \pm 1.14$ & & $0.014^{*}$ \\
\hline Before nursing care & & & \\
\hline After nursing care & $7.96 \pm 2.74$ & 2.626 & \\
\hline Financial assistance & $7.60 \pm 2.44$ & & 0.326 \\
\hline Before nursing care & & & \\
\hline After nursing care & $10.73 \pm 3.60$ & 1.000 & \\
\hline Family functioning & $10.66 \pm 3.56$ & & \\
\hline Before nursing care & & & \\
\hline After nursing care & $5.46 \pm 2.01$ & 2.664 & \\
\hline
\end{tabular}

$* \mathrm{p}<0.05$

\begin{tabular}{|l|l|}
\hline Table 3. Distribution of the nursing diagnoses & $\mathbf{n}(\boldsymbol{\%})$ \\
\hline Nursing diagnoses* & $30(100.0)$ \\
\hline Fear & $28(93.3)$ \\
\hline Deficient knowledge & $23(76.7)$ \\
\hline Feeding, oral, dressing and bathing self-care deficit & $13(43.3)$ \\
\hline Imbalanced nutrition: less than body requirements & $13(43.3)$ \\
\hline Ineffective respiratory tract cleaning & $12(40.0)$ \\
\hline Constipation & $7(23.3)$ \\
\hline Readiness for enhanced knowledge & $5(16.7)$ \\
\hline Trend risky health behavior & $5(16.7)$ \\
\hline Disturbed sleep pattern & $4(13.3)$ \\
\hline Delay in growth and development & $3(10.0)$ \\
\hline Readiness for enhanced relationship & $2(6.7)$ \\
\hline Risk for other-directed violence & $2(6.7)$ \\
\hline Impaired physical mobility & $1(3.3)$ \\
\hline Imbalanced nutrition: more than body requirement & $1(3.3)$ \\
\hline Interrupted family processes & $1(3.3)$ \\
\hline Chronic sorrow (mother) & $1(3.3)$ \\
\hline Risk for aspiration & $1(3.3)$ \\
\hline Readiness for enhanced fluid balance & $1(3.3)$ \\
\hline Risk for self-directed violence & $1(3.3)$ \\
\hline Anxiety & $1(3.3)$ \\
\hline Caregiver role strain & \\
\hline
\end{tabular}

*More than one choice was marked. 
to Others Need", "Social Service Need", "Family Functioning Need" before and after nursing care $(p<0.05)$. It was determined that FNAT total scores, information, support, explanation to others, social service and family functioning needs of the families decrease after nursing care (Table 2).

The needs expressed by the mothers as answers to open-ended questions were sorted and examined according to the priority levels. Medical, psychological support, care, rehabilitation, education and social life needs are high, especially prior to nursing care. The priority levels of knowledge, psychological support and homecare need decreased.

The nursing diagnoses made according to the data acquired from the Child and Family Introduction Form and Sick Child Diagnosis Form are shown in Table 3. The most frequent diagnoses are "Fear", "Deficient Knowledge", "Feeding", "Oral, Dressing and Bathing Self-Care Deficit", "Imbalanced Nutrition: Less Than Body Requirement", "Ineffective Respiratory Tract Cleaning", "Constipation".

\section{DISCUSSION}

In our study, almost all of the families did not know in advance, that they would have a disabled child. All participants stated that they could cope with the condition of their children. This suggested that families, most of whose children are above the age of 4 years, had passed through the denial, anger and depression stages of bereavement following the diagnosis of disability, and that they are currently in the acceptance stage. A study showed that the negative emotions experienced by the parents when their children are diagnosed with a disability are replaced with positive, optimistic and accepting emotions in time, and that they strive to enhance the care of their child. ${ }^{2}$

In our study, the primary caregiver for the disabled child was the mother in all cases. A study carried out on physically disabled children found that $91 \%{ }^{10}$ of the caregivers are mothers; another study also showed that in families with mentally disabled children that this ratio is $80.5 \%{ }^{13}$ The results of our study are concordant with these studies.

Many studies showed that parents of disabled children experience psychological ${ }^{3,4,10}$ and physical problems (such as hypertension, fatigue, pain) more than parents of normal children. ${ }^{10}$ In our study, many mothers complain about lumbago and lumbar hernia as a result of the physical difficulties involved in taking care of the child. Future anxiety is also very prevalent among the mothers in our study.

In our study, mothers were lacking in knowledge of oral care, feeding, toilet, cleaningwashing and many other issues involved in caring for a disabled child. They demanded aid in areas of education, social support, economic and social life. Altuğ Özsoy et al. ${ }^{12}$ carried out a study on families with mentally disabled children and found that $45.5 \%$ of the families experience difficulties in the treatment stage of their children, $43.6 \%$ experience disappointment and $54.5 \%$ experience continuous anxiety related to the future. The study carried out by K1liç ${ }^{10}$ on the families of physically disabled children found that, children require help from their caregivers for the daily activities such as walking, eating, sitting down and standing up, taking a bath, wearing clothes and taking clothes off and going to the restroom. As a result of the study carried out by Yavuz and Çimen, ${ }^{14}$ children with cerebral palsy are lacking in self care in areas including sleep-restinghaving fun, cleaning, oral care, toilet and eating. Abelson $^{15}$ determined that families need help related with issues such as preparing the food for the children, giving medications, bathing, oral care, feeding, putting on diapers, going to toilet, putting on clothes, protecting the child from danger and self-injuries inflicted by the children. The results of our study are in accordance with this literature.

It was determined that problems such as mental retardation, epilepsy, visual and aural disabilities, speech disorders, nausea, vomiting, dysphagia, chronic pulmonary aspiration, gastroesophageal reflux (GOR), chronic constipation, eating disorders are physical and mental disabilities in children. ${ }^{16}$ Whereas complications such as difficulty with chewing (dysphagia) and difficulty with swallowing, aspiration pneumonia, constipation, abdominal distension, ${ }^{17}$ epilepsy, difficulty in feeding ${ }^{18}$ are seen frequently. It was observed in the study carried out by Erdoğanoğlu and Günel ${ }^{19}$ on children with cerebral palsy that problems related to with vision, speaking and hearing as well as epileptic seizures were observed in the children. Cokpekin et al. ${ }^{20}$ determined that oral care is insufficient in disabled children. Durduran ${ }^{21}$ determined that $5 \%$ of disabled children have asthma or bronchitis and $7.4 \%$ have health problems such as epilepsy. In concordance with the literature, our study showed that children with disabilities have additional health problems such as drooling, caries, bronchitisasthma, epilepsy, and constipation as well.

It was determined in our study that $70 \%$ of the disabled children continue going to the rehabilitation center. Another study showed that $78.1 \%$ undergo physical therapy. ${ }^{10}$ The reason for 
this high ratio is thought to be related to the fact that physical therapy and rehabilitation are offered free of charge to disabled children in our country.

Late or premature births, hypoxia and trauma due to difficult labor, genetic and chromosomal disorders, prenatal infections, diseases and accidents experienced by the mother during pregnancy, drugs, and toxins are among factors that cause disabilities in children. ${ }^{22}$ The children of families participated in our study have become disabled because of genetic disorders, diseases, birth trauma and hypoxia. Thyen et al. ${ }^{11}$ determined that the most frequent reasons for disability in children are inflammatory brain injuries, perinatal brain traumas and genetic malformations.

It was determined that almost half of the children who participated in the study take medicine regularly. Yavuz and Çimen ${ }^{14}$ found in their study that $27.1 \%$ of the children take medicine regularly.

A statistically significant difference was determined in the total FNAT score, "Information Need" and "Support Need" subscale scores with respect to child's age $(\mathrm{p}<0.05)$. Children between the ages of 4 and 6 and 7 to 12 years comprised the majority of the study participants. These are preschool and school age groups. The preschool period is important for preparing the child for school attendance. It is thought that means of "Information Need" and "Support Need" subscale scores are high because families do not have enough knowledge as to whether their disabled child will be able to go to school or not, or to which school the child should go based on the type of disability. In the meantime, it is thought that the mean "Explanation to Others Need" subscale score is high in 7 to 12 age group in which children start school, they take a more active social role and start asking more questions of the family members. The reason of higher mean "Financial Need" subscale scores for the families of 0 to 3 year age group children can be explained by children in this age group requiring more treatment and rehabilitation. Moreover, additional financial loads imposed by as diapers and special infant formula. It was determined in the study carried out by Akçamete and $\mathrm{Karg}_{10}{ }^{5}$ on children with hearing disability that the needs of families change according to the age of the child.

In our study mean "Support Need" subscale scores differed significantly with respect to child's gender. Families with girls need more support $(\mathrm{p}<0.05)$. This is thought to be because families believe girls with disabilities are more prone to abuse, and thus their parents tend to feel more anxious. However, contrary to our study results,
Akçamete and Kargın ${ }^{5}$ determined in their study that mothers with boys need more support.

A negative correlation was determined between the age of the mother and "Information Need" and "Support Need" subscale scores $(\mathrm{p}<0.05, \mathrm{p}<0.001)$. This result can be explained by the fact that young mothers lack knowledge about child rearing and child care and thus need more support with these issues.

Visits to the homes of the disabled children and their families enable monitoring the interaction between the family members, ${ }^{23}$ evaluation of the family in general, determination of the behavioral problems of the child at an early stage, receiving knowledge about the child's development, health and care in their own home; these visits also enable health officials to provide support to the family thus making it easier for them to have access to health services. $^{24}$

Nursing care carried out with these home visits enables the required nursing care to be given to the families based on their specific needs, determine the problems of individual family members with the strengths of the child and family members and to utilize these strengths. It enhances the communication between the child, family and team members, while also ensuring the continuity of care. ${ }^{25}$ It was determined in our study that the area in which families need the most support prior to nursing care is "Support Need" followed by "Information Need". A statistically significant difference was determined between the total and subscale scores of FNAT before and after nursing care except "Financial Needs" subscale score $(p<0.05)$. It was determined in the study carried out by Akçamete and Kargin ${ }^{5}$ that the first need of mothers is "Information Need", the second is "Financial Needs"; another study also determined that families have economic needs. ${ }^{6}$ Other studies carried out determined that families need social services, information, ${ }^{9}$ psychosocial consulting, care coordination ${ }^{11}$ and home care. ${ }^{8}$

The information, psychological support and homecare needs of families decreased after nursing care. It is thought that the reason for the change in the priority list of needs is the training given during home visits by the nurse, as well as the homecare given.

\section{How might this information affect nursing practice?}

Disabled children need nursing care in every moment of their lives. Homecare nurses play an important role in decreasing the load on families with sick children. Nurses help in the application of 
homecare for the child as well as with the adaptation of the family to the child's condition by establishing a positive communication with the family. The homecare nurse plans nursing practices in accordance with the needs of the family and child, carries them out and evaluates the results obtained from their interaction with the family. Nurses provide training and consultancy about the different fields of knowledge that the family needs while also providing a family-centered and holistic care service. ${ }^{25}$ They establish support groups consisting of families with similar problems and help families to cope with stress. They give information to the families about the sources regarding practices they can access and put into practice. These support practices carried out by the nurse decrease the stress on the family ensure the continuity of long term care while increasing its quality. $^{26}$

\section{Limitations and Difficulties}

The study was conducted with only a small group. We were unable to choose an equal number of age groups because the families of children in some age groups did not accept participation in the study and did not recognize some disability (such as mental retardation) among children in the 0 to 3 year age group. We also had difficulty finding the addresses of the family during a home visit.

\section{Conclusions}

The needs of families decreased at a statistically significant level following nursing care except the "Financial Need". These study results showed that the nursing care provided for disabled children and their families via home visits is effective in reducing the needs of the families. Based on these findings, it is suggested that:

- The health needs of disabled children and their families are evaluated at regular intervals and that the health services required are provided by the nurses at the homes of the disabled children.

- A free-of-charge homecare system only for disabled children should be established.

- The established homecare system is provided by a team of nurses, doctors, dentists, physical therapists and psychologists who have received the relevant training on children.

It is suggested that a multidisciplinary health team including a nurse who can give training on child care and health requirements to families shoul be present in institutions provide physical therapy and rehabilitation services to disabled children.

\section{Acknowledgments}

The authors received no financial support for the research, authorship, and/or publication of this article. The authors declare no potential conflicts of interest with respect to the research, authorship, and/or publication of this article. All authors meet the criteria for authorship, have designed, provided analysis and interpreted the data, drafted, revised and approved the final article and those entitled to authorship are listed as authors.

*This study is master's thesis and presented as poster in 4. Pediatric Nursing Congress, Turkey, 2013

\section{REFERENCES}

1. World Health Organization. World Report on Disability. Geneva. 2011 (Accessed 18/9)

http://www.who.int/disabilities/world_repor t/2011/en/

2. Heiman T. Parents of children with disabilities: resilience, coping, and future expectations. Journal of Developmental and Physical Disabilities. 2002;14:159-171.

3. Akandere $\mathrm{M}$, Acar $\mathrm{M}$, Baştuğ $\mathrm{G}$. Investigating the hopelessness and life satisfaction levels of the parents with mental disabled child. Selçuk Üniversitesi Sosyal Bilimler Enstitüsü Dergisi. 2009;22:23-33.

4. Keskin G, Bilge A, Engin E, Dülgerler Ş. The evaluation of anxiety, parental attitude and coping strategy in parents of children with mental retardation. Anatolian Journal of Psychiatry. 2010;11:30-37.

5. Akçamete G, Kargın T. Determination of the needs of hearing impaired children's mothers. Özel Eğitim Dergisi. 1996;2:7-24.

6. Busch SH, Barry CL. Mental health disorders in childhood: assessing the burden on families. Health Affairs. 2007;4:1088-1095.

7. Xiong N, Yang L, Yu Y, Hou J, Li J, Li Y. et al. Investigation of raisingburden of children with autism, physical disability and mental disability in China. Research in Developmental Disabilities. 2011;32:306311.

8. Aktaş E. The systematic review of the researches which light the way for homecare requirements of physically disabled children and their families. (Unpublished Master's Thesis). University of Marmara, Institute of Health Sciences, İstanbul. 2010; p. 74.

9. Buran CF, Sawin K, Grayson P, Criss S. Family needs assessment in cerebral palsy clinic. JSPN. 2009;14:87-93. 
10. Kılıç S. The effect of homecare needs on the families of the physically disabled children. (Unpublished Master's Thesis). University of Marmara, Institute of Health Sciences, İstanbul. 2009; p. 36-52.

11. Thyen U, Sperner J, Morfeld M, Meyer C, Ravens-Sieberer U. Unmet health care needs and impact on families with children with disabilities in Germany. Ambulatory Pediatrics. 2003;3:74-81.

12. Altuğ ÖS, Özkahraman Ş, Çallı F. Review of hardships undergone by families with mentally retarded children. Aile ve Toplum Dergisi. 2006;8:69-77.

13. Yıldırım Sarı H, Başbakkal Z. Developing "A family burden assessment scale" for the families of children with intellectual disability. Atatürk Üniversitesi Hemşirelik Yüksekokulu Dergisi. 2008;11(3):86-95.

14. Yavuz B, Çimen S. Investigation of the fulfilment levels of the self-care skills of the children with cerebral palsy and affectional factors. Cumhuriyet Üniversitesi Hemşirelik Yüksekokulu Dergisi. 2007;11(1):17-26.

15. Abelson AG. Respite care needs of parents of children with developmental disabilities. Focus on Autism and Other Disabilities. 2009;14:96-100.

16. Colver A, Fairhurst C, Pharoah POD. Cerebral palsy. Lancet. 2014;383:1240-49.

17. Pane M, Vasta I, Messina S, Sorleti D, Aloysius A, Sciarra $F$ et al. Feeding problems and weight gain in duchenne muscular dystrophy. Europe an Journal of Paediatric Neurology. 2006;10:231-236.

18. Raphaela AR, Couthouisa J, Sakamuri S, Siskind C, Vogel H, Day J W, et al. Congenital muscular dystrophy and generalized epilepsy caused by GMPPB mutations. Brain Res. 2014;5:66-71.
19. Erdoğanoğlu $Y$, Kerem Günel $M$. Investigation of the relationship between motor and functional levels with healthrelated quality of life in children with cerebral palsy. Toplum Hekimliği Bülteni. 2007;26:13-18.

20. Çokpekin F, Köymen G, Başak F, Akbulut $\mathrm{E}$, Altun $\mathrm{C}$. The evaluation of oral health of children attending the school of handicapped children. Gülhane Tıp Dergisi. 2003;45:228-232.

21. Durduran Y. Health problems of disabled children apart from their disabilities and their health service utility: case-control study. (Upublished Doctoral Thesis). University of Selçuk, Institute of Health Sciences, Konya. 2009; p. 35.

22. Centers for Disease Control and Prevention. Intellectual Disability (Also Known As Mental Retardation) Fact Sheet. 2012 (Accessed 3/7) http://www.cdc.gov/ncbddd.

23. Öztek Z, Kubilay G, editors. The community health nursing. 3rd ed. Ankara: Palme publishing; 2005. p. 230-249.

24. Bilukha O, Hahn RA, Crosby A, Fullilove MT, Liberman A, Moscicki E et al. The effectiveness of early childhood home visitation in preventing violence, a systematic review. Am J PrevMed 2005;28:11-39.

25. Potts NL, Mandleco BL, editors. Pediatric nursing: caring for children and their families. USA: Delmar Thomson Learning; 2012. p.15-107-108).

26. World Health Organization. Collection on Long-Term Care, Key Policy Issues In Long-Term Care. Geneva. 2003. p.3-15. (Accessed http://apps.who.int/iris/bitstream/10665/426 04/1/9241562250.pdf 